\title{
NRG1 Gene
}

National Cancer Institute

\section{Source}

National Cancer Institute. NRG1 Gene. NCI Thesaurus. Code C20174.

This gene plays a role in cellular differentiation, growth and proliferation. 